\title{
Risk analysis and support for the integrated rescue system on emergencies
}

\author{
M. Dzermansky, R. Pekaj, \\ Tomas Bata University in Zlin \\ Czech Republic
}

Received: September 30, 2020. Revised: November 6, 2020, Accepted: November 9, 2020. Published: November $12,2020$.

\begin{abstract}
The protection of the population is one of the basic aspects of the contemporary world. As well as an integrated rescue system that performs the tasks of protection of the population and has the task of minimizing the impact of emergencies and their rescue and liquidation work. Today, emergency plans include individual analyzes that help point out possible risks and also help integrated rescue system units prepare for them.
\end{abstract}

Keywords- Analysis, Integrated rescue system, population protection, software

\section{INTRODUCTION}

To population protection and protection from individual risks, cities set up measures to prevent and to intervene on time. The basic elements of this protection are the components of the integrated rescue system which is actively involved in the fight against individual risks. Other elements are loud announcements which include a uniform warning and notification system for the population. It is important to map individual risks. [4, 8, 11]

\section{MethodOLOGY}

The method of analysis was used in this work. It is a process of intellectual or real decomposition of the examined object into individual parts, which become the subject of further research. It is one of the most widely used scientific methods. The analyses were used to select risks that were applied to the Qualitative analysis of risks using their correlation method.

The second method is the Qualitative analysis of risks using their correlation method. The method is used to identify the most probable and greatest risks that may arise and to divide them into quadrants according to danger. This method is therefore used to determine the most serious risks from the selected list.

\section{SECURITY SITUATION}

All units of the integrated rescue system are located in the city of Kyjov. There are the state police of the Czech Republic, the municipal police of the Czech Republic, the medical rescue corps, the fire rescue corps, and the volunteer fire brigade.
The Police of the Czech Republic is one of the uniform armed security corps established by the act of the Czech national council by the 21 st of June 1991 . The task of the state police is to protect persons and property, protect public order, and prevent crime. Other tasks of the police also include the fulfillment of tasks under the criminal procedure code and other tasks in the field of internal order and security entrusted by its laws, regulations of the European Communities, and international treaties, which are part of the legal order. [13]

The municipal police have a total of 18 officers and provide round the clock service to be able to assist in any situation. In addition to the duty to supervise public order, the municipal police also check offenses committed by speeding in the municipality, using a laser speed meter available at the service. Also, they have a CCTV system to monitor the city's order and control the traffic system. The municipal police station is located on Masaryk square. Municipal police equipment consists of company cars, service handcuffs, service weapons, telescopic truncheons, pepper spray, radio, and catching gloves. [1]

Emergency medical systems in Kyjov include hospitals and the health center. Hospital is a complex facility that provides outpatient and inpatient care for the inhabitants of the Hodonin district. In the fields of internal medicine, surgery, pediatric, gynecological-obstetric, and department of Anaesthesiology and Intensive Care the hospital provides care for approximately 162000 inhabitants of the Hodonin district together with the hospital in Hodonin. In-patient care which includes orthopedics, neurology, dermal, urology, rehabilitation, eye, lung, ear-nose-throat, and infectious, provides institutional care separately. There are 47 outpatient clinics on the premises of the Kyjov hospital, some of which are located in the health center in the center of Kyjov and others in the cities of Hodonin and Veseli nad Moravou. Hospital equipment: ambulances (26), operating vehicles (9), reference vehicles (5), funeral vehicles (1).

The health center provides professional care from general practitioners. There are 5 general practitioners and departments of hepatology clinic, orthopedic clinic, surgical clinic, and central X-ray. [9]

The fire rescue service of the city of Kyjov is classified under the category JPO / II. This category means that after a fire alarm is issued, it goes to the triggered case within 5 
minutes. Fire rescue service Kyjov currently consists of 20 members. Individual members of the congregation have individual tasks: carrier of respiratory equipment, chainsaw operator, population protection technician. [3]

\section{EVALUATION OF BASIC AREAS OF POPULATION PROTECTION}

The city of Kyjov announces warnings with the help of sirens and local radio. In the city of Kyjov fire is not declared but the siren function is maintained in the event of a crisis and population awareness. This alert system also includes local detectors of the information system to warn the population in the event of a flood or other emergency. The broadcasting station is stored in the Kyjov municipal police and the building of elementary school and kindergarten in Bohuslavice. A total of 168 wireless detectors and 393 speakers are installed in Kyjov and 56 sound detectors and 129 loudspeakers have been installed for the sound and reporting of the parts of Bohuslavice, Borsov, and Netcice. Persons in catchment areas threatened by floods in the Kyjov are warned:

- triggering of the siren - warning signal "general warning" with the addition of the verbal information "Danger of flood wave",

- reporting on the local radio about flood risks, expected threats, including basic instructions and measures to endanger the population,

- by phone or SMS, personal communication (pedestrian link, megaphones).

These warnings are carried out by the flood authority of the city of Kyjov, eventually by the fire brigade, by the flood commission of the municipality with extended competence, the police of the Czech Republic, or another authorized person.

Verbal information using electronic siren: General Alert "General Alert, General Alert, General Alert. Watch the broadcasts of Czech Radio, Television, and Regional Radio. General Alert, General Alert, General Alert".

Examples of alerts and notifications to residents using local radio: "Dear fellow citizens, based on the decision of the flood authority of the town of Kyjov, the second (third) level of flood activity was declared in the town - state of emergency (threat)."

In case of failure of technical equipment for announcing extraordinary events, the alarm is issued manually. For example, the city uses TV Slovacko or radio car for warning inhabitants about the danger. [7, 15, 16]

\section{EVACUATION}

In the city of Kyjov is the possibility of emergency accommodation of evacuated persons in the buildings of the primary school of Jan Amos Komensky, primary school of Dr. Joklik, and the hostel on the street Havlickova and the secondary vocational school on the street Havlickova. The total capacity of the evacuation sites is approximately 660 people. Possible self-evacuation in about $50 \%$ of the endangered persons is considered. The possibility of substitute accommodation is only at dormitories and hotels in Kyjov. These centers include: [14]

- TRIFIN PLUS, SPOL. s.r.o. - maximum capacity of 110 persons,

- 596 s.r.o. - Hotel Club *** - maximum capacity of 55 persons,

- TJ Jiskra Kyjov (Municipal Stadium) - maximum capacity of 30 people,

- City hostel - maximum capacity of 100 people. [14, 2]

As part of the emergency supply in the event of a crisis, there is the possibility of considering the use of retail chains in Kyjov for food supply. These chains supply basic food, hygiene products, and protective equipment involved in emergency supply.

Emergency drinking water supply is provided by the supply of drinking water in the form of bottled water or tanks by the interruption of the water supply from all sources. Water for public use, it means water intended for drinking and cooking is imported in a crisis from the source Vrt Dukla, located at a distance of about $9 \mathrm{~km}$. Emergency supplies also envisage the use of local resources such as wells and service water sources. In the event of a prolonged crisis, a new resource would have to be set up. [12]

Informing the population is done through mass media such as television or radio. Using these methods, citizens are familiar with the type and nature of the danger. In addition to these techniques, citizens can also be informed by local systems such as municipal radio, cable television, or radio police cars. $[7,16]$

Individual protection of the population includes common domestic means available to people. These products are referred to as improvised body protection and include gloves, scarves, outerwear, ski goggles, raincoats, rubber boots, and all that can protect the human body. These funds replace the standard means of individual protection as a gas mask which would be issued to selected groups of the population only in the event of a state of emergency and a state of war. $[6,10]$

Throughout the South Moravian region, which also includes the city of Kyjov, humanitarian aid is provided by the PANEL. PANEL is a group of non-profit organizations. These nonprofits include the Czech red cross, Diocesan charity, ADRA, and People in need. These non-profit organizations are prepared to provide the necessary material, spiritual, psychosocial but also financial assistance to the population affected by a crisis or emergency in a state of crisis. [5]

\section{ANALYSIS}

The Qualitative analysis of risks using their correlation method is used to identify the most probable and greatest risks that may arise and to divide them into quadrants by hazard. 
To perform the Qualitative analysis of risks using their correlation method correctly, it is necessary to compile a list of risks that are set for the given object and it is necessary to insert them into the table. For the internal action of the ball type the following 10 risks are identified which may arise in the object.

\begin{tabular}{|c|c|c|c|c|c|c|c|c|c|c|c|}
\hline$\underline{\underline{R i s k s}}$ & 1 & 2 & 3 & 4 & 5 & 6 & 7 & 8 & 9 & 10 & Summary \\
\hline Floods & 0 & 1 & 0 & 1 & 1 & 1 & 1 & 0 & 1 & 0 & 6 \\
\hline Fire & 1 & 0 & 0 & 1 & 1 & 1 & 1 & 1 & 1 & 0 & 7 \\
\hline Terrorism & 0 & 1 & 0 & 1 & 0 & 1 & 1 & 0 & 1 & 1 & 6 \\
\hline Power outage & 0 & 1 & 0 & 0 & 1 & 1 & 1 & 0 & 0 & 0 & 4 \\
\hline Vandalism and disorder & 0 & 1 & 0 & 1 & 0 & 1 & 1 & 0 & 1 & 0 & 5 \\
\hline Traffic accidents & 0 & 1 & 0 & 1 & 1 & 0 & 1 & 0 & 1 & 0 & 5 \\
\hline Leakage of dangerous chemicals & 0 & 1 & 0 & 1 & 1 & 1 & 0 & 1 & 1 & 1 & 7 \\
\hline Drought & 1 & 1 & 0 & 0 & 0 & 1 & 1 & 0 & 1 & 1 & 6 \\
\hline Outage of drinking water supply & 0 & 0 & 0 & 0 & 1 & 1 & 0 & 1 & 0 & 0 & 3 \\
\hline Epidemic & 0 & 0 & 0 & 1 & 1 & 1 & 1 & 1 & 1 & 0 & 6 \\
\hline Summary & 2 & 6 & 0 & 7 & 7 & 9 & 8 & 4 & 8 & 3 & \\
\hline
\end{tabular}

Figure 1. List of risks

Calculation of the $K_{A R i}$ activity coefficient for individual risks $R_{i}$ :

$$
\begin{aligned}
& \mathrm{K}_{\text {ARi }}-\frac{\sum \mathrm{Ri}}{\mathrm{x}-1} \cdot 100[\%] \\
& \text { 1. } \mathrm{K}_{\text {ARi }}=\frac{\sum \mathrm{Ri}}{\mathrm{x}-1} \cdot 100[\%]=\frac{6}{10-1} \cdot 100=\frac{6}{9} \cdot 100=66,66 \% \\
& \text { 2. } \mathrm{K}_{\text {ARi }}=\frac{\sum \mathrm{Ri}}{x-1} \cdot 100[\%]=\frac{7}{10-1} \cdot 100=\frac{7}{9} \cdot 100=77,77 \% \\
& \text { 3. } \mathrm{K}_{\text {ARi }}=\frac{\sum \mathrm{Ri}}{\mathrm{x}-1} \cdot 100[\%]=\frac{6}{10-1} \cdot 100=\frac{6}{9} \cdot 100=66,66 \% \\
& \text { 4. } \mathrm{K}_{\text {ARi }}=\frac{\sum \mathrm{Ri}}{x-1} \cdot 100[\%]=\frac{4}{10-1} \cdot 100=\frac{4}{9} \cdot 100=44,44 \% \\
& \text { 5. } \mathrm{K}_{\text {ARi }}=\frac{\sum \mathrm{Ri}}{x-1} \cdot 100[\%]=\frac{5}{10-1} \cdot 100=\frac{5}{9} \cdot 100=55,55 \% \\
& \text { 6. } \mathrm{K}_{\text {ARi }}=\frac{\sum \mathrm{Ri}}{x-1} \cdot 100[\%]=\frac{5}{10-1} \cdot 100=\frac{5}{9} \cdot 100=55,55 \% \\
& \text { 7. } \mathrm{K}_{\text {ARi }}=\frac{\sum \mathrm{Ri}}{x-1} \cdot 100[\%]=\frac{7}{10-1} \cdot 100=\frac{7}{9} \cdot 100=77,77 \% \\
& \text { 8. } \mathrm{K}_{\text {ARi }}=\frac{\sum \mathrm{Ri}}{\mathrm{x}-1} \cdot 100[\%]=\frac{6}{10-1} \cdot 100=\frac{6}{9} \cdot 100=66,66 \% \\
& \text { 9. } \mathrm{K}_{\text {ARi }}=\frac{\sum \mathrm{Ri}}{x-1} \cdot 100[\%]=\frac{3}{10-1} \cdot 100=\frac{3}{9} \cdot 100=33,33 \% \\
& \text { 10. } \mathrm{K}_{\text {ARi }}=\frac{\sum \mathrm{Ri}}{x-1} \cdot 100[\%]=\frac{6}{10-1} \cdot 100=\frac{6}{9} \cdot 100=66,66 \%
\end{aligned}
$$

Figure 2. Calculation of the KARi

$$
\begin{aligned}
& \text { Calculation of the passivity coefficient } \mathbf{K}_{\mathrm{PRi}} \text { for individual risks } \mathbf{R}_{\mathrm{i}} \text { : } \\
& \mathrm{K}_{\mathrm{PRi}}-\frac{\sum \mathrm{Ri}}{\mathrm{x}-1} \cdot 100[\%] \\
& \text { 1. } \mathrm{K}_{\mathrm{PRi}}=\frac{\sum \mathrm{Ri}}{x-1} \cdot 100[\%]=\frac{2}{10-1} \cdot 100=\frac{2}{9} \cdot 100=22,22 \% \\
& \text { 2. } \mathrm{K}_{\mathrm{PRi}}=\frac{\sum \mathrm{Ri}}{x-1} \cdot 100[\%]=\frac{6}{10-1} \cdot 100=\frac{6}{9} \cdot 100=66,66 \% \\
& \text { 3. } \mathrm{K}_{\mathrm{PRi}}=\frac{\sum \mathrm{Ri}}{x-1} \cdot 100[\%]=\frac{0}{10-1} \cdot 100=\frac{0}{9} \cdot 100=0 \% \\
& \text { 4. } \mathrm{K}_{\mathrm{PRi}}=\frac{\sum \mathrm{Ri}}{x-1} \cdot 100[\%]=\frac{7}{10-1} \cdot 100=\frac{7}{9} \cdot 100=77,77 \% \\
& \text { 5. } \mathrm{K}_{\mathrm{PRi}}=\frac{\sum \mathrm{Ri}}{x-1} \cdot 100[\%]=\frac{7}{10-1} \cdot 100=\frac{7}{9} \cdot 100=77,77 \% \\
& \text { 6. } \mathrm{K}_{\mathrm{PRi}}=\frac{\sum \mathrm{Ri}}{x-1} \cdot 100[\%]=\frac{9}{10-1} \cdot 100=\frac{9}{9} \cdot 100=99,99 \% \\
& \text { 7. } \mathrm{K}_{\mathrm{PRi}}=\frac{\sum \mathrm{Ri}}{x-1} \cdot 100[\%]=\frac{8}{10-1} \cdot 100=\frac{8}{9} \cdot 100=88,88 \% \\
& \text { 8. } \mathrm{K}_{\mathrm{PRi}}=\frac{\sum \mathrm{Ri}}{x-1} \cdot 100[\%]=\frac{4}{10-1} \cdot 100=\frac{4}{9} \cdot 100=44,44 \% \\
& \text { 9. } \mathrm{K}_{\mathrm{PRi}}=\frac{\sum \mathrm{Ri}}{x-1} \cdot 100[\%]=\frac{8}{10-1} \cdot 100=\frac{8}{9} \cdot 100=88,88 \% \\
& \text { 10. } \mathrm{K}_{\mathrm{PRi}}=\frac{\sum \mathrm{Ri}}{x-1} \cdot 100[\%]=\frac{3}{10-1} \cdot 100=\frac{3}{9} \cdot 100=33,33 \%
\end{aligned}
$$

Figure 3. Calculation of the KPRi

The result of the method is a correlation graph. The graph is divided into four quadrants:
- I. quadrant - an area of primary and secondary risks (Traffic accidents, leakage of dangerous chemicals).

- II. Quadrant - secondary hazardous area (Outage of drinking water supply).

- III. Quadrant - area of primarily dangerous risks (floods, fire, terrorism, power outage, vandalism and disorder, drought, epidemic).

- IV. Quadrant - a relatively safe area.

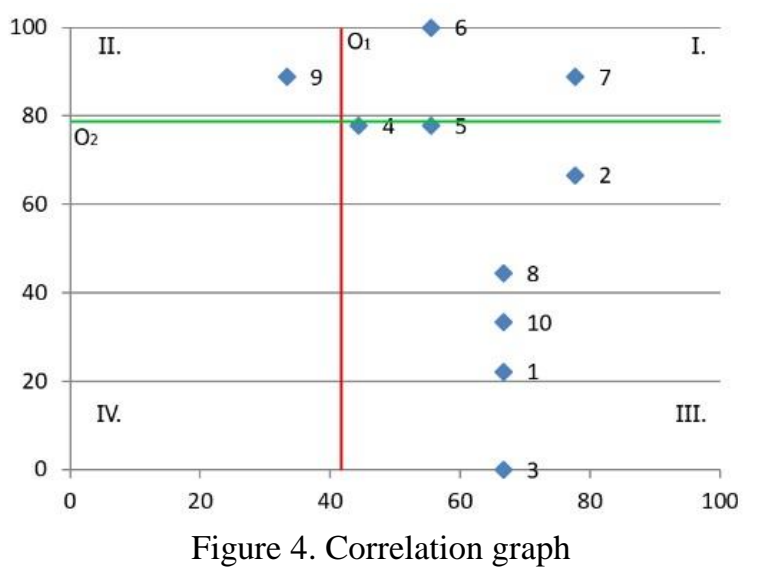

\section{SUPPORT FOR THE INTEGRATED RESCUE SYSTEM ON EMERGENCIES}

An emergency can be described as the harmful effects of forces and phenomena caused by human activities, natural influences, as well as accidents that endanger life, health, property, or the environment and require rescue and liquidation work. Therefore, an emergency can be considered as a sudden serious event that caused a disturbance in the stability of the system with a possible threat to its security or existence.

In the previous chapter, dealing with risk analysis, a qualitative analysis of risks was used, using their correlation, which was used to point out the most serious risks. However, is it sufficient to perform risk analyzes to reduce their occurrence or direct elimination? Not by far. To prepare and respond to emergencies on time, it is also necessary to carry out verification and tactical exercises of the integrated rescue system that intervenes in emergencies.

Support for integrated rescue system exercises is therefore the most important part of emergency preparedness. According to the act in the Czech Republic as amended by No. 239/2000 Coll., on the integrated rescue system and $\S 17$, the examination exercise is carried out to verify the preparation of the components of the integrated rescue system for rescue and liquidation work. [10]

Tactical exercises are carried out to prepare the components of the integrated rescue system and the bodies involved in the implementation and coordination of rescue and liquidation work in emergencies. The holding of the tactical exercise is discussed in advance with the involved units and bodies. 
By law, the Minister of the interior is entitled to order a verification as well as a tactical exercise by the directorgeneral of the fire and rescue service, the regional governor, or the director of the regional fire and rescue service.

From the qualitative analysis of risks using their correlation, the biggest risks were a traffic accident and a leakage of a dangerous chemical substance. For their timely elimination and preparedness, an integrated rescue system exercise focused on this type of emergency could help.

The T-SOFT crisis software package, which includes TerEx, POSIM, OBNOVA, and PRACTIS software, can be used to create exercises and streamline emergency procedures.

PRACTIS software helps to textually but also graphically represent the connection of the whole exercise. All participants in the accident are listed here, for example from notifier to the individual units of the integrated rescue system (fire brigade, ambulance service, and police of the Czech Republic). Among other things, there is an operational information center among the participants, which receives emergency calls and then commissions the units of the integrated rescue system to intervene.

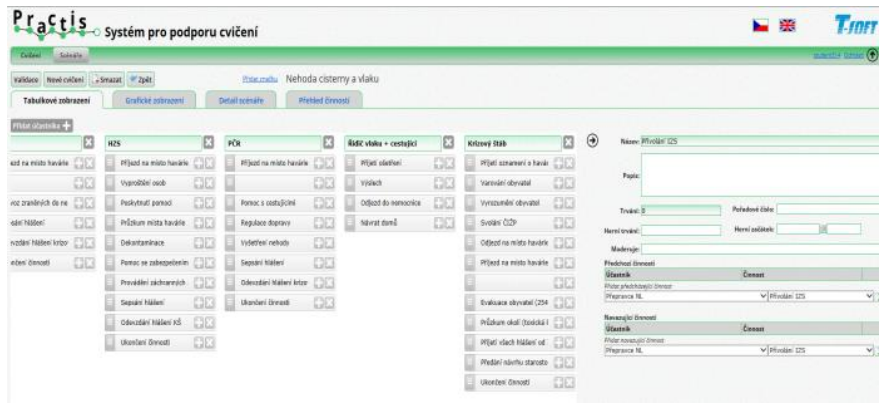

Figure 5. SW PRACTIS

Each of the participants is assigned their tasks such as from the notifier of the emergency notification, the operational information center reception, and the instruction to leave the units of the integrated rescue system and their coordination and other sub-tasks for all participants.

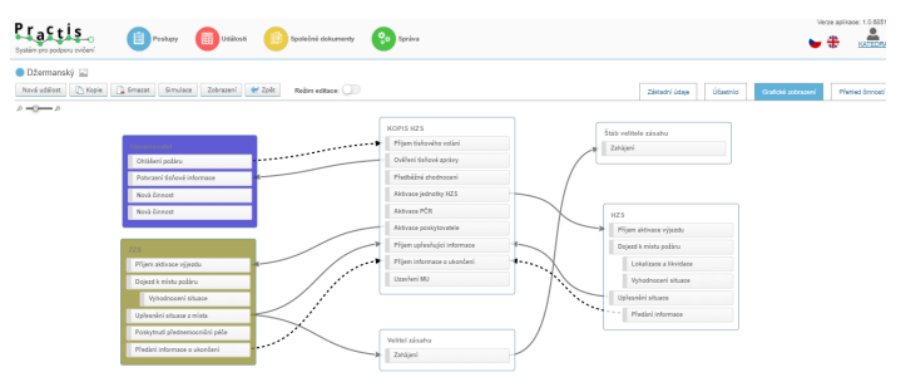

Figure 6. SW PRACTIS - Graph

The second software suitable for creating exercises is software TerEx. This software is suitable for simulating the leakage of hazardous substances and, thanks to the connection to the geographic information system, also for marking the necessary evacuation of the population from the affected area.

The software is based on the selection of a hazardous substance and also gives the choice of whether from a liquid or gaseous base. TerEx is also able to use elements such as wind speed per hour, the part of the day in which the emergency continued, the temperature of the substance, or the determination of the wind direction.

The result of this software is a map showing the necessary evacuation of the population using the elements that have been selected. The simulation created in this way can greatly help the integrated rescue system to practice even more serious accidents with the release of a dangerous substance, as they can anticipate how serious the accident will be and how many people will need to be evacuated.

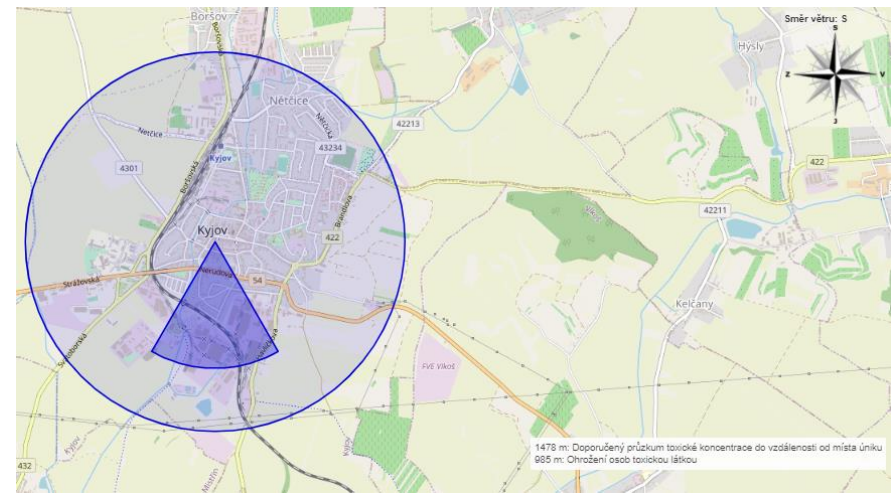

Figure 7. SW TerEx - Map

\section{DISCUSSION AND CONCLUSION}

In this paper are given information about preparedness for the emergencies in the city of Kyjov, analysis and integrated rescue system and exercises. The preparation of individual towns and villages is primarily based on an integrated rescue system. These units are ready to depart for individual incidents that may occur. The city of Kyjov have all these units and have prepared individual plans for the implementation of rescue work and measures to prevent these events. The city of Kyjov consists of 12000 inhabitants and with the capacity of individual corps can ensure sufficient safety for its inhabitants. A sufficient uniform warning and notification system has been set up in the city to warn and inform the residents of any emergency. Alternative information channels have also been set up in the event of a power outage and these systems ceased to function.

The Paper describes the individual units of the integrated rescue system and the evaluation of basic areas of population protection. The part of the paper is a Qualitative analysis of risks using their correlation analysis, which could help the city to identify the most dangerous risks and to create its remedies and prevent them. This method is based on 10 risks, which 
were further divided into four resulting quadrants using activity and passivity ratios, indicating their severity.

Chapter number seven discusses how to better prepare for emergencies. Mere risk analyzes are not enough, so it is necessary to create such exercises of the integrated rescue system and thus improve their preparedness and effectiveness in the fight against emergencies. From the qualitative analysis of risks using their correlation was found that the biggest risks are traffic accidents and leakage of hazardous substances. It was therefore proposed to create exercises in two programs, PRACTIS and TerEx. These programs could help to better prepare for emergencies but are not used by the integrated rescue system. The application of these tools could therefore help alleviate these emergencies.

\section{References}

[1] City police equipment. Mp.mestokyjov.cz [online]. Kyjov: mp.mestokyjov.cz, c2020 [cit. 2020-02-03]. Retrieved from: http://mp.mestokyjov.cz/O-nas/vybaveni.html

[2] Evacuation area [online]. Praha: edpp.cz, 2016 [cit. 202002-02]. Retrieved from: https://www.edpp.cz/kyj_zabezpeceni-evakuacedocasneho-ubytovani-a-stravovani-evakuovanych-obcanua-jejich-navrat/

[3] Fire and rescue service Kyjov [online]. Kyjov: Fire and rescue service Kyjov, 2017 [cit. 2020-02-02]. Retrieved from: http://hasicikyjov.webnode.cz/o-nas/

[4] Hradil A et al 2018 Basics of population protection in the Czech Republic: professional monograph (Uherske Hradiste: Tomas Bata University in Zlín) ISBN 9788074547744.

[5] Humanitarian aid [online]. Brno: Fire Brno, 2013 [cit. 2020-02-02]. Retrieved from: http://www.firebrno.cz/humanitarni-pomoc

[6] Individual protection [online]. Brno: Fire Brno, 2013 [cit. 2020-02-02]. Retrieved from: http://www.firebrno.cz/individualni-ochrana

[7] Informing the population [online]. Brno: Fire Brno, 2013 [cit. 2020-02-02]. Retrieved from: http://www.firebrno.cz/informovani-obyvatelstva

[8] KRÖMER et al 2010 Risk mapping: spectrum (Association of Fire and Safety Engineering) ISBN 9788073850869.

[9] Kyjov Hospital [online]. kyjov: Kyjov Hospital, 2017 [cit. 2020-02-02]. Retrieved from: http://www.nemkyj.cz/charakteristika-nemocnice

[10] Law. Czech Republic. § 17 zákona č. 239/2000 Sb., o integrovaném záchranném systému a o změně některých zákonů. In: Zákony pro lidi.cz [online]. C AION CS 2010-2020 [cit. 15. 9. 2020]. Dostupné z: https://www.zakonyprolidi.cz/cs/2000-239\#p17[

[11] Population protection and crisis management 2015: script. Prague: (Ministry of the Interior - General Directorate of the Fire and Rescue Service of the Czech Republic). ISBN 978-80-86466-62-0. S. Chen, B. Mulgrew, and P. M. Grant, "A clustering technique for digital communications channel equalization using radial basis function networks," IEEE Trans. Neural Networks, vol. 4, pp. 570-578, July 1993.

[12] Pokludova P 2012 The system of logistical support for catering in crisis situations for the city of Kyjov: bachelor thesis (Uherske Hradiste: Tomas Bata Univerzity in Zlín)

[13] Police of the Czech Republic [online]. Praha: Policie ČR, 2017 [cit. 2020-02-02]. Retrieved from: http://www.policie.cz/clanek/o-nas-policie-ceskerepubliky-policie-ceske-republiky.aspx

[14] Population evacuation [online]. Brno: HZS, 2013 [cit. 2020-02-02]. Retrieved from: http://www.firebrno.cz/evakuaceAnother reference

[15] Warning area [online]. Kyjov: Kyjov, 2016 [cit. 2020-0202]. Retrieved from: www.mestokyjov.cz/assets/File.ashx?id_org=7843\&id_do kumenty=26081

[16] Warning measures [online]. Praha: edpp.cz, 2016 [cit. 2020-02-02]. Retrieved from: https://www.edpp.cz/kyj_varovna-opatreni/

\section{Creative Commons Attribution License 4.0} (Attribution 4.0 International, CC BY 4.0)

This article is published under the terms of the Creative Commons Attribution License 4.0 https://creativecommons.org/licenses/by/4.0/deed.en_US 